\title{
THE EFFECT OF BLOOD CONTAMINATION ON SHEAR BOND STRENGTH OF CALCIUM SILICATE-BASED PULP CAPPING MATERIALS
}

\begin{abstract}
Objectives: The aim of this study was to examine the effect of different hardening times and blood contamination of MTA and Biodentine, which are widely used for pulp capping treatments in the market, on shear bond strength (SBS) with a self-etch adhesive resin, after different hardening times (24, 48, 72 and 96 hours).
\end{abstract}

Materials and Methods: Slots with a diameter of $5 \mathrm{~mm}$ and a height of $2 \mathrm{~mm}$ were prepared in 192 acrylic blocks for this study. Both ProRoot MTA and Biodentine were prepared according to the manufacturer's instructions, and half of the slots were filled with ProRoot MTA and the other half were filled with Biodentine. All the samples were divided into groups depending on four different hardening times and hardened. After the hardening process was completed, the group of each hardening time was divided into 2 subgroups (n:12) with and without contamination.

In the uncontaminated groups, a self-etch adhesive resin (Clearfil Liner Bond) and a resinbased composite (Filtek P60) were applied on the samples and polymerized. In the contaminated groups, the sample surfaces were contaminated with blood for 20 seconds. After washing and drying the samples, adhesive resin and composite were applied on them. After that, SBS tests were performed and the data were subjected to a 2-way ANOVA test analysis.

Results: In the uncontaminated groups, there was no significant difference in the SBS of each pulp capping material depending on different hardening times ( $p>0.05$ ). ProRoot MTA showed statistically higher SBS than Biodentine in the 72 and 96 hour uncontaminated groups $(\mathrm{p}<0.05)$. Blood contamination caused a significant decrease in the SBS of ProRoot MTA and Biodentine $(\mathrm{p}<0.05)$.

Conclusions: In this study, it was determined that blood contamination reduces the SBS of pulp capping materials. Therefore, it is recommended to prolong the hardening times of the capping materials and to take clinical measures to prevent blood contamination as much as possible before restorative treatments are performed.

Keywords: Pulp Capping; MTA; Biodentine; Blood Contamination; Shear Bond Strength.

\author{
Hasan Fatih Yavuz ${ }^{1}$ \\ *Güneş Bulut Eyüboğlu ${ }^{1}$
}

\footnotetext{
${ }^{1}$ Department of Restorative Dentistry, School of Dentistry, Karadeniz Technical University, Ortahisar/Trabzon, Turkey.
}

How to Cite Yavuz HF, Bulut Eyüboğlu G. The Effect of Blood Contamination on Shear Bond Strength of Calcium Silicate-Based Pulp Capping Materials. Cumhuriyet Dent J 2021;24:4:371-385.

*Corresponding Author:

Department of Restorative Dentistry, School of Dentistry, Karadeniz Technical University, Ortahisar/Trabzon, Turkey.

$\begin{array}{lll}\text { Phone: + } 904623774731-4715 & \text { Fax: + } 904623253017 \quad \text { E-mail: gnsblt2011@gmail.com }\end{array}$

ORCID IDs of the authors:

H.F.Y. $\quad$ 0000-0003-4404-7874

G.B.E. 0000-0002-0033-7135 


\section{INTRODUCTION}

Pulp capping treatments (PCT) aim to maintain the vitality of the pulp by directly covering the pulp tissue exposed for various reasons with a capping material. ${ }^{1,2}$ Deep dentin caries, exposure of the pulp tissue due to mechanical or traumatic reasons are the most important factors that threaten the vitality of the pulp. In such cases, it is of great importance to allow the tooth to function in the mouth for a much longer time by maintaining the vitality of the pulp, in terms of contributing to phonation and aesthetics. It is aimed at maintaining the vitality of the pulp by ensuring the formation of tertiary dentin with the capping material applied over the exposed pulp tissue. ${ }^{2,3}$

Various pulp capping materials have been introduced to the market for use in PCT so far. Although calcium hydroxide $(\mathrm{CH})$ has been used as the gold standard in PCTs for many years, ${ }^{1}$ it has disadvantages such as high solubility and lack of adhesion to dental tissues. In PCT with $\mathrm{CH}$, it has been reported that the dentin bridge formed by $\mathrm{CH}$ has tunnel defects and porosities ${ }^{4,5}$, and $\mathrm{CH}$ has an inability of adhesion to the dentin surface, so it causes microleakage in the long term and does not protect the pulp sufficiently. ${ }^{6}$

As a result of the search for different materials due to the disadvantages of $\mathrm{CH}$, ProRoot MTA (Densply, Tulsa Dental, USA), developed by Torabinejad et $a l^{7,8}$, at Loma Linda University in 1993, is the first calcium silicate-based (CSB) cement used in dentistry. MTA has advantages such as providing a more homogeneous (containing less tunnel defect) dentin bridge formation in a shorter time compared to $\mathrm{CH}$, causing less inflammatory reaction, hardening in the presence of moisture, meeting high chewing pressure after hardening, and being biocompatible. ${ }^{9}$ MTA is used for PCT, pulpotomy, repair of root perforations, bifurcation lesions, internal and external root resorption, apexification and as the apical plug material in endodontic surgery and deep cervical and radicular lesions. ${ }^{10,11}$ Although MTA currently continues to be used successfully in PCT, it has maintained a different material trend in this area due to its disadvantages such as having long hardening time and not being economical. ${ }^{7,12}$
Biodentine (Septodont, France), developed in 2009, contains tricalcium silicate, calcium carbonate, calcium oxide and zirconium oxide in its powder and it is a CSB material containing modified polycarboxylate and calcium chloride components in its liquid. The main advantages of Biodentine are initial hardening time of approximately 12 minutes and enhanced physical properties according to the manufacturer's instructions. ${ }^{13}$ Biodentine, which is a biocompatible material, is used in the treatment of pulp capping, amputation, apexification and root perforation repair and as retrograde root filling. ${ }^{14,15}$ Biodentine stimulates odontoblast-like cells by forming mineralization nodules in dentin and provides dentin-like matrix formation. ${ }^{16}$ It stimulates mineralization by releasing calcium ions and creates a mineral infiltration zone at the dentincementum interface, providing better coverage and reducing microleakage. ${ }^{17}$ Biodentine is similar to MTA in terms of forming dentin bridge formation and causing lower inflammation in the pulp. ${ }^{18}$ According to the manufacturer's instructions, the shorter hardening time of Biodentine is an advantage, for the restorative procedures can be performed in a shorter time compared to MTA, which has an initial hardening time of 3-4 hours. ${ }^{7}$

In PCT, after the exposed pulp tissue is covered with pulp capping materials, temporary restorations are frequently made on them to complete their hardening, and the capping material is expected to harden. After the pulp capping materials harden for a certain time period, the temporary filling is removed and permanent restorations are completed with adhesive and composite resins.

There are different literature data on the different hardening times of capping materials, affecting bond strength to adhesive resins. ${ }^{19-22}$ In addition, it is often possible for the capping material to be exposed to oral fluids and blood contamination from the gingiva after hardening and prior to the construction of the upper restoration in clinical conditions. Moreover, an uncontaminated capping material has a different surface microstructure compared to the capping material exposed to blood contamination. ${ }^{23}$ Therefore, blood contamination could affect the 
shear bond strength (SBS) of the capping material to adhesive resins. Hovewer, to the best of our knowledge, a study on the effect of blood contamination of the capping materials on the SBS to restorative materials after hardening is not available in the literature.

For this reason, our first aim in this study was to investigate the SBS of ProRoot MTA and Biodentine, which are CSB capping materials widely used in PCT, to a self-etch adhesive resin after different hardening times $(24,48,72,96$ hours). Our second aim is to investigate the effect of blood contamination in vitro of ProRoot MTA and Biodentine after different hardening times $(24,48$, 72,96 hours) on SBS to a self-etch adhesive resin. follows:

Our initial hypotheses in this study were as

1. There is no difference between the SBS of ProRoot MTA and Biodentine to a self-etch adhesive resin after different hardening times (24, $48,72,96$ hours).

2. Blood contamination of ProRoot MTA and Biodentine after different hardening times $(24,48$, 72,96 hours) does not affect the SBS to a selfetch adhesive.

\section{MATERIAL AND METHODS}

\section{Ethics}

Ethical approval was obtained from the Health Ethics Committee of Karadeniz Technical University, Faculty of Medicine, Scientific Research Ethics Committee in Trabzon, Turkey (ID: 2019/294 and decision date 18.11.2019).

In this in vitro study, the effect of two CSB pulp capping materials, ProRoot MTA (Densply, Tulsa Dental, USA) and Biodentine (Septodont, Saint-Maurdes, France) on SBS to a two-step selfetch adhesive, Clearfil Liner Bond F (Kuraray Noritake Dental Inc, Japan) and a microhybrid composite (Filtek P60 Posterior Composite, 3M ESPE, Dental Products, USA) after different hardening times $(24,48,72,96$ hours) was investigated. Furthermore, the effect of blood contamination of these pulp capping materials after these different hardening times on SBS was also investigated.

The materials used in the study, their contents, production numbers and application instructions are shown in Table 1.

Table 1. Materials, Contents, Production Numbers and Application Instructions

\begin{tabular}{|c|c|c|c|}
\hline MATERIALS & $\begin{array}{c}\text { BATCH } \\
\text { NUMBERS }\end{array}$ & CONTENTS & APPLICATION INSTRUCTIONS \\
\hline $\begin{array}{c}\text { ProRoot White MTA } \\
\text { (Densply, Tulsa Dental, } \\
\text { USA) }\end{array}$ & 0000249678 & $\begin{array}{l}\text { Powder: Tricalcium aluminate, } \\
\text { tricalcium silicate, silicate oxide and } \\
\text { tricalcium oxide, iron oxide, } \\
\text { magnesium and bismuth oxide } \\
\text { Liquid: distilled water, saline } \\
\mathrm{Ph}=12-13\end{array}$ & $\begin{array}{l}\text { Mix } 1 \text { pack of powder with } 1 \text { ampule } \\
\text { of liquid for about } 1 \text { minute. After } \\
\text { application, it is closed with damp } \\
\text { cotton and temporary filling is made. } \\
\text { After } 96 \text { hours, permanent filling is } \\
\text { applied. }\end{array}$ \\
\hline $\begin{array}{l}\text { Biodentine } \\
\text { (Septodont, Saint-Maur- } \\
\text { desFosses, France) }\end{array}$ & B25453 & $\begin{array}{l}\text { Powder: Tricalcium silicate, } \\
\text { dicalcium silicate, calcium carbonate, } \\
\text { iron oxide, zirconium oxide } \\
\text { Liquid: Calcium chloride, } \\
\text { hydrosoluble polymer, water }\end{array}$ & $\begin{array}{l}\text { The capsule is opened and } 5 \text { drops of } \\
\text { liquid from the disposable liquid are } \\
\text { dropped into the capsule. The capsule } \\
\text { is closed and placed in the } \\
\text { amalgamator and mixed for } 30 \\
\text { seconds at } 4500 \mathrm{rpm} \text { (rotation/min). } \\
\text { The capsule is opened and the } \\
\text { Biodentin material is applied with the } \\
\text { appropriate handpiece. }\end{array}$ \\
\hline
\end{tabular}




\section{Clearfil Liner Bond F}

(Kuraray Noritake Dental Inc., Japan)

\section{Filtek P60 Posterior} Composite

(3M ESPE, Dental

Products, USA)

Primer: 10-Methacryloyloxydodecyl

dihydrogen phosphate (MDP),

2-hydroxyethyl methacrylate (HEMA), Hydrophilic aliphatic dimethacrylate,

dl-camphorquinone,

1. The primer is applied to the tooth surface and waited for 20 seconds. N,N-di-ethanol-p-tolidine, Water.

\section{$\mathrm{Ph} \approx 1.9$}

000019

Bond: 10-Methacryloyloxydodecyl phosphate (MDP),

2-hydroxyethyl methacrylate (HEMA),

Bisphenol A digicidyl methacrylate (Bis-GMA), Colloidal silica,

Hydrophobic aliphatic

dimethacrylate, dl-camphoroquinone, $\mathrm{N}, \mathrm{N}$-diethanol p-tolidine

It contains Zirconia / Silica and BiS- It is applied with the incremental GMA, UDMA and BIS-EMA resin. technique in $2 \mathrm{~mm}$ masses and The inorganic filler content is $61 \%$ by polymerized with a dental light volume.
Oil-free air is squeezed to allow solvents to evaporate and disappear.

2. Bond is applied to the tooth surface and oil-free air is gently squeezed to form a uniform layer.

3 . The adhesive is cured with a dental light device that emits light at a wavelength of $400-515 \mathrm{~nm}$ for 10 seconds.

device for 20 seconds

\section{Preparation of Test Samples}

A total of 192 cylindrical acrylic blocks with a diameter of $30 \mathrm{~mm}$ and a height of $10 \mathrm{~mm}$ were prepared by forming 16 groups (n:12) for 4 different hardening times and contamination groups for each CSB capping material. Slots with a diameter of $5 \mathrm{~mm}$ and a height of $2 \mathrm{~mm}$ were prepared in these 192 acrylic blocks. For each setting time of each pulp capping material, 24 samples were prepared and half of them were used in experiments with blood contamination and the other half in experiments without blood contamination (Table 2).

Table 2: Experimental Groups Prepared According to Different Hardening Times and Contamination Conditions of MTA and Biodentine

\begin{tabular}{|c|c|c|c|c|}
\hline 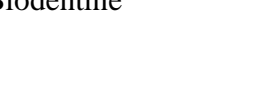 & & $\begin{array}{c}192 \\
\text { Samples } \\
\end{array}$ & & \\
\hline \multicolumn{2}{|c|}{$\begin{array}{c}\text { MTA } \\
\text { n:96 }\end{array}$} & & \multicolumn{2}{|c|}{$\begin{array}{c}\text { BIODENTINE } \\
\text { n:96 }\end{array}$} \\
\hline $\begin{array}{c}\text { MTA 24 } \\
\text { Contamination (-) } \\
\text { (n:12) } \\
\end{array}$ & $\begin{array}{c}\text { MTA 24 } \\
\text { Contamination (+) } \\
(\mathrm{n}: 12) \\
\end{array}$ & & $\begin{array}{c}\text { Biodentine } 24 \\
\text { Contamination (-) } \\
\text { (n:12) } \\
\end{array}$ & $\begin{array}{c}\text { Biodentine } 24 \\
\text { Contamination (+) } \\
(\mathrm{n}: 12) \\
\end{array}$ \\
\hline $\begin{array}{c}\text { MTA 48 } \\
\text { Contamination (-) } \\
\text { (n:12) } \\
\end{array}$ & $\begin{array}{c}\text { MTA 48 } \\
\text { Contamination (+) } \\
(\mathrm{n}: 12) \\
\end{array}$ & & $\begin{array}{c}\text { Biodentine } 48 \\
\text { Contamination (-) } \\
\text { (n:12) } \\
\end{array}$ & $\begin{array}{c}\text { Biodentine } 48 \\
\text { Contamination (+) } \\
(\mathrm{n}: 12) \\
\end{array}$ \\
\hline $\begin{array}{c}\text { MTA 72 } \\
\text { Contamination (-) } \\
\text { (n:12) }\end{array}$ & $\begin{array}{c}\text { MTA 72 } \\
\text { Contamination (+) } \\
(\mathrm{n}: 12)\end{array}$ & & $\begin{array}{c}\text { Biodentine } 72 \\
\text { Contamination (-) } \\
(\mathrm{n}: 12)\end{array}$ & $\begin{array}{c}\text { Biodentine } 72 \\
\text { Contamination (+) } \\
(\mathrm{n}: 12)\end{array}$ \\
\hline $\begin{array}{c}\text { MTA 96 } \\
\text { Contamination (-) } \\
\text { (n:12) }\end{array}$ & $\begin{array}{c}\text { MTA 96 } \\
\text { Contamination (+) } \\
(\mathrm{n}: 12)\end{array}$ & & $\begin{array}{c}\text { Biodentine 96 } \\
\text { Contamination (-) } \\
(\mathrm{n}: 12)\end{array}$ & $\begin{array}{c}\text { Biodentine } 96 \\
\text { Contamination (+) } \\
\text { (n:12) }\end{array}$ \\
\hline
\end{tabular}

ProRoot MTA and Biodentine were applied to the slots prepared in acrylic blocks according to the manufacturer's instructions. The surface of the MTA samples was covered with moist cotton and all the prepared samples were hardened for the planned times $(24,48,72,96 \mathrm{~h})$ by storing them at $37^{\circ} \mathrm{C}$ and $100 \%$ humid environment.

\section{In uncontaminated groups (without blood}

contamination), after certain hardening times, Clearfil Liner Bond F, a two-step self-etch 
adhesive system, was applied on the pulp capping materials according to the manufacturer's instructions and polymerized with light (Elipar S10, 3M ESPE) for 20 seconds. After polymerization, a $3 \mathrm{~mm}$ high composite resin (Filtek P60, 3M ESPE) was applied on the capping materials in layers of $1.5 \mathrm{~mm}$ thickness each, using a mold and each layer was polymerized with light for 20 seconds again.

In the contaminated groups (with blood contamination), after certain hardening times, the surfaces of the pulp capping materials were contaminated with fresh blood for 20 seconds. After that, the surfaces were washed with water for 10 seconds and then dried by wiping once with a cotton roll. After the contamination and drying processes, adhesive resin and composite applications were performed and then all the samples were kept in a $100 \%$ humid environment at 37 degrees for 24 hours.

\section{Shear Bond Strength Test}

SBS test was applied to all the samples with a Universal Tension/Compression Testing Machine (Instron 3382, USA) at a speed of $0.5 \mathrm{~mm} / \mathrm{min}$. After the SBS test, the results were converted to Megapascals (MPa). The fracture surfaces of the samples were examined with an optical microscope (Olympus Metallurgical Microscope) under X30 magnification, and different failure types (adhesive, cohesive and mixed) were determined.

\section{Statistical analysis}

SPSS for Windows 17.0 (SPSS Inc., Chicago, USA) program was used for statistical analysis. Normal distribution analysis of the data was performed with the Shapiro Wilk test. Two-way ANOVA test and Fisher's LSD test were used for repetitive samples and paired samples test was used for time-dependent variations. A $\mathrm{p}<0.05$ level was considered statistically significant in all the analyses.

\section{RESULTS}

\section{Shear Bond Strength Test Results}

Interactions are reported in Table 3. According to the interaction table, SBS test values were significantly influenced by both time (p: 0.029) and time $\mathrm{x}$ material (p: 0.007) whereas no effects were found for interactions (time $x$ contamination), (p: 0.341) and (time $\mathrm{x}$ material $\mathrm{x}$ contamination), (p: 0.274).

Table 3. Two-way ANOVA interaction effects for shear bond strength

\begin{tabular}{lccccc}
\hline Source & Value & F & Hypothesis df & Error dF & Sig. p \\
\hline Time & .192 & 3.3 & 3 & 42 & .029 \\
Time* Material & .249 & 4.6 & 3 & 42 & .007 \\
Time* Contamination & .076 & 1.1 & 3 & 42 & .341 \\
Time* Material* Contamination & .087 & 1.3 & 3 & 42 & .274 \\
\hline
\end{tabular}

df: degrees of freedom.

${ }^{*} p<0.05$; level was considered statistically significant.

1- Comparisons of SBS Results of Pulp Capping Materials Hardened at Different Times within Groups

Table 4 shows the mean and standard deviation values of SBS according to the different hardening times $(24,48,72,96 \mathrm{~h})$ and contamination status of the capping materials used in the study, as well as within-group differences. 
Table 4. Mean and Standard Deviation Values of Shear Bond Strength (MPa) and Comparisons within Groups

PULP CAPPING

MATERIALS /

24 HOURS

48 HOURS

72 HOURS

96 HOURS

HARDENING TIME

\begin{tabular}{|c|c|c|c|c|}
\hline MTA & $20.46 \pm 3.97^{\mathrm{A}}$ & $22.50 \pm 4.52^{A}$ & $23.75 \pm 5.81^{A}$ & $22.65 \pm 4.11^{\mathrm{A}}$ \\
\hline $\begin{array}{l}\text { CONTAMINATED } \\
\text { MTA }\end{array}$ & $\begin{array}{c}10.43 \pm 2.42^{\mathrm{A}} \\
{ }^{*} \mathrm{p}<0.05 \text { ( with contMTA48) } \\
{ }^{*} \mathrm{p}<0.05 \text { (with contMTA72) } \\
{ }^{*} \mathrm{p}<0.05 \text { (with contMTA96) }\end{array}$ & $14.92 \pm 5.20^{\mathrm{B}}$ & $16.80 \pm 2.52^{\mathrm{B}}$ & $17.14 \pm 3.38^{\mathrm{B}}$ \\
\hline BIODENTINE & $18.61 \pm 5.51^{\mathrm{A}}$ & $20.32 \pm 3.04^{\mathrm{A}}$ & $18.01 \pm 3.46^{\mathrm{A}}$ & $18.55 \pm 3.40^{\mathrm{A}}$ \\
\hline $\begin{array}{l}\text { CONTAMINATED } \\
\text { BIODENTINE }\end{array}$ & $13.25 \pm 3.74^{\mathrm{A}}$ & $11.72 \pm 3.25^{\mathrm{A}}$ & $13.40 \pm 6.06^{\mathrm{A}}$ & $12.26 \pm 1.97^{\mathrm{A}}$ \\
\hline
\end{tabular}

According to Bonferroni correction, a significant difference in shear bond strength of each pulp capping material at different hardening times (in the same row) is shown in superscript. Different letters indicate statistical differences in rows ( $p<0.05$ ).

When the SBS values were examined statistically,

There was no statistically significant difference between the groups in terms of SBS after different hardening times $(24,48,72,96$ hours) for the noncontaminated MTA group ( $\mathrm{p}>0.05$ ). Contaminated (Cont) MTA24 group showed statistically significantly lower bond strength compared to Cont MTA48, 72, 96 hour groups $(\mathrm{p}<0.05)$.

There was no statistically significant difference between the groups after different setting times (24, 48, 72, 96 hours) for the uncontaminated Biodentine group ( $\mathrm{p}>0.05)$. For the Contaminated (Cont) Biodentine group, there was no statistically significant difference between the groups after different setting times $(24,48,72$, 96 hours) ( $p>0.05)$.

\section{2- Comparison of the Shear Bond Strength Test} Results of Pulp Capping Materials Among the Groups within the Same Hardening Time

Comparison of the SBS values of contaminated and uncontaminated MTA and Biodentine groups with each other in the same hardening time group is given in Table 5 .

Table 5. Comparison of the SBS Values Among the Groups within the Same Hardening Time

\begin{tabular}{|c|c|c|c|c|}
\hline \multirow{2}{*}{$\begin{array}{l}\text { PULP CAPPING } \\
\text { MATERIALS }\end{array}$} & \multicolumn{4}{|c|}{ Hardening Times } \\
\hline & 24 HOURS & 48 HOURS & 72 HOURS & 96 HOURS \\
\hline MTA & $\begin{array}{c}\mathbf{2 0 . 4 6} \\
* \mathrm{p}<0.01 \\
\text { (with Cont.MTA24) }\end{array}$ & $\begin{array}{c}\mathbf{2 2 . 5 0} \\
* \mathrm{p}<0.01 \\
\text { (with Cont.MTA 48) }\end{array}$ & $\begin{array}{c}\mathbf{2 3 . 7 5} \\
* \mathrm{p}<0.05 \\
(\text { with Cont. MTA 72) } \\
* * \mathrm{p}<0.05 \text { (with BD72) }\end{array}$ & $\begin{array}{c}\mathbf{2 2 . 6 5} \\
* \mathrm{p}<0.01 \\
\text { (with Cont. MTA 96) } \\
* * \mathrm{p}<0.05 \text { (with BD 96) }\end{array}$ \\
\hline $\begin{array}{c}\text { CONTAMINATED } \\
\text { MTA }\end{array}$ & 10.43 & 14.92 & 16.80 & $\begin{array}{c}\mathbf{1 7 . 1 4} \\
{ }^{* *} \mathrm{p}<0.01 \\
\text { (with Cont.BD 96) }\end{array}$ \\
\hline BIODENTINE & $\begin{array}{l}\text { 18.61 } \\
* \mathrm{p}=0.002 ; \mathrm{p}<0.01 \\
\text { (with Cont.BD 24) }\end{array}$ & $\begin{array}{c}\mathbf{2 0 . 3 2} \\
{ }^{*} \mathrm{p}<0.01 \\
\text { (with Cont.BD 48) }\end{array}$ & $\begin{array}{c}\mathbf{1 8 . 0 1} \\
* \mathrm{p}<0.05 \\
\text { (with Cont.BD 72) }\end{array}$ & $\begin{array}{c}\mathbf{1 8 . 5 5} \\
{ }^{*} p<0.01 \\
\text { (with Cont.BD 96) }\end{array}$ \\
\hline $\begin{array}{l}\text { CONTAMINATED } \\
\text { BIODENTINE }\end{array}$ & 13.25 & 11.72 & 13.40 & 12.26 \\
\hline
\end{tabular}

*: It refers to the significant differences in the same hardening time (in the same column) of the contaminated and uncontaminated groups of the same pulp capping material.

** : It refers to the significant difference in the same hardening time of two different materials (MTA-Biodentine). Different letters indicate statistical differences in rows $(\mathrm{p}<0.05)$.

$\mathrm{BD}$ is used as an abbreviation for Biodentine.

When the shear bond strength values of MTA and Biodentine groups were compared with each other in the same hardening time,

There was no statistically significant difference between SBS at the end of the 24-hour and 48hour hardening times of the uncontaminated MTA and Biodentine groups ( $\mathrm{p}>0.05)$.
However, the SBS of MTA72 group (23.75 $\mathrm{MPa}$ ) was found to be statistically higher than that of the Biodentine72 group (18.01 MPa) at the end of the 72 hour hardening period $(p<0.05)$. Similarly, at the end of the 96 hour hardening time, the mean SBS of the MTA group (22.65 $\mathrm{MPa})$ was statistically significantly higher than 
the mean SBS of the Biodentine group (18.55 $\mathrm{MPa})(\mathrm{p}<0.05)$.

\section{When the Contaminated MTA and Contaminated Biodentine groups were compared,}

At the end of the 24, 48, 72 hour setting time, there was no statistically significant difference between the SBS values of the Cont. MTA24, 48, 72 groups and those of the Cont. Biodentine 24, 48,72 groups ( $p>0.05$ ). At the end of the 96-hour hardening period, SBS values of the Cont. MTA96 group were found to be significantly higher than the SBS values of the Cont. Biodentine96 group $(\mathrm{p}<0.05)$.

The Bar Graphic showing the Contamination Status of the Pulp Capping Materials and the S values according to the different setting times is as in Figure 1.

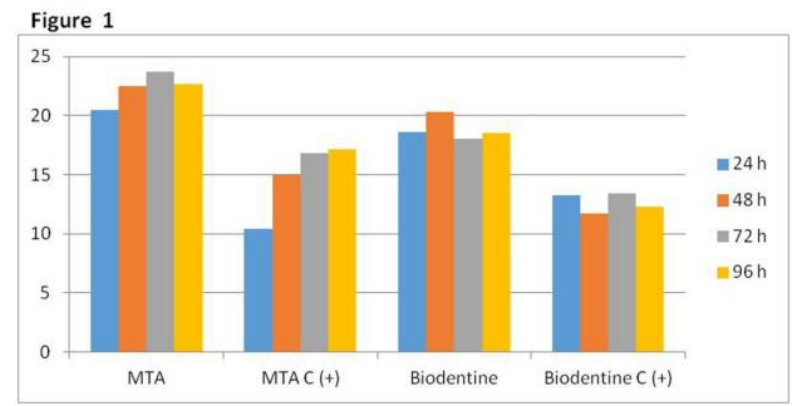

Figure 1. Bar graphic of shear bond strength values by capping material/contamination conditions and hardening time.

Evaluation of Stereomicroscope Images of Fractured Surfaces

In Figure 2, in the uncontaminated MTA groups, the failures were predominantly cohesive, but the adhesive failures increased as the hardening time increased.

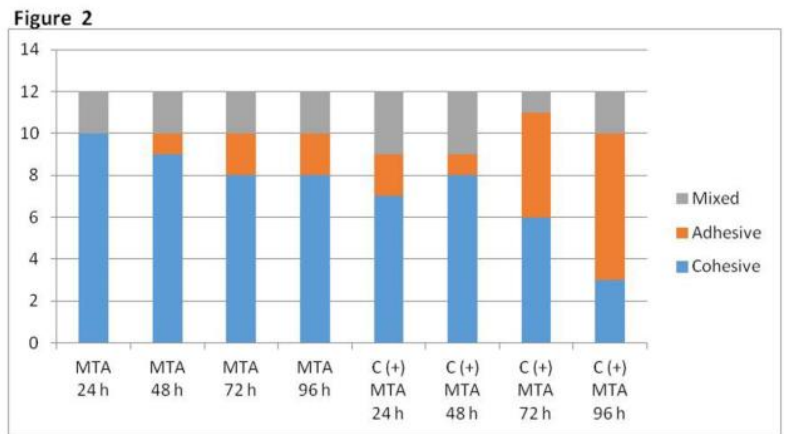

Figure 2. Distribution of failure types at different hardening times of MTA. C(+) means blood contamination.

In the Cont. MTA groups, the group with the highest rate of adhesive failure was the group hardening for 96 hours.
As seen in Figure 3, cohesive failures were mostly observed in the uncontaminated Biodentine groups. Adhesive failure type was more commonly seen in the Cont. Biodentine groups, particularly in the Cont. Biodentine 24 group.

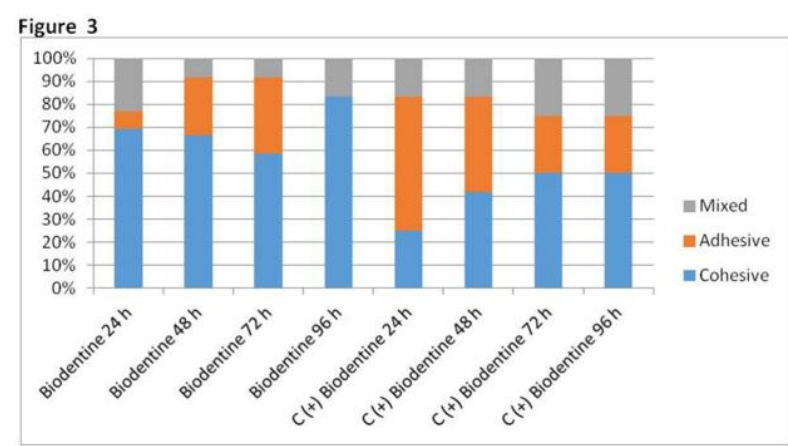

Figure 3. Distribution of failure types at different hardening times of Biodentine. $\mathrm{C}(+)$ means blood contamination.

\section{DISCUSSION}

Although different materials have been used in PCT in the literature to date, MTA and Biodentine are CSB materials preferred in PCT due to their advantages such as biocompatibility, high level of sealing properties, and forming reparative dentin formation depending on cell differentiation. . $^{14,15,18,24-}$ 26 Studies have shown that these materials stimulate the release of TGF- $\beta 1$ and that this growth factor provides reparative dentin regeneration from pulp stem cells and the dentin bridge, which is formed by the effect of both MTA and Biodentine, is less porous. ${ }^{27,28}$

PCT should be followed by an impermeable upper restoration that prevents bacterial invasion at the restoration and dentin interface. That is because the prevention of microleakage and the high bond strength between the pulp coating material and the restoration are also factors that ensure the continuity of the vitality and function of the tooth. ${ }^{29}$ For this reason, the upper restoration made in capping treatments is expected to show sufficient bond strength to the capping material used in the deepest part of the cavity, as well as to the tooth tissues.

Today, adhesive resins are the most preferred permanent restorative materials due to their aesthetic properties. Although there are many studies in the literature investigating the bond strength of direct pulp capping materials to dental 
adhesives, different and contradictory results have been obtained in the bond strength of capping materials to adhesive resins after different hardening times in different studies. ${ }^{19,22,30,31}$

However, there are different factors that can affect the bond strength of composite resins to capping materials in clinical conditions. During the restorative treatments in the clinical conditions, leakage of saliva and blood into the cavity during the different stages of restorative material applications will cause contamination of the surface and pose a risk for the bond strength of the restoration. ${ }^{32,33}$ Although there have been studies examining the bond strength of MTA and Biodentine to various adhesives, as far as we know, we have not come across any study on the effect of blood contamination of these materials on SBS.

Therefore, in this study, the effect of different hardening times $(24,48,72,96 \mathrm{~h})$ and blood contamination of CSB capping materials (ProRoot MTA and Biodentine) on SBS to a two-step selfetch adhesive resin (Clearfil Liner Bond F) and a mycrohybrid composite resin (Filtek P60) was investigated in-vitro. According to the findings of this study, there was no statistically significant difference between the SBS values of uncontaminated ProRoot MTA at different hardening times $(p>0.05)$. There was no statistical difference between the bond strength values of the uncontaminated Biodentine at different hardening times ( $p>0.05)$. The bond strength values of both MTA and Biodentine groups after all hardening times were found to be equal to or higher than the clinically expected bond strength (17-20 MPa) (Table 4).

When the uncontaminated MTA and Biodentine groups at the same hardening time were compared, no statistically significant difference was observed between the SBS at 24 and 48 hours, while the SBS of MTA groups hardening for 72 and 96 hours were found to be statistically significantly higher than the Biodentine72 and Biodentine96 groups $(\mathrm{p}<0.05)$, (Table 5). Therefore, the first hypothesis of our study, "There is no difference between the SBS of
ProRoot MTA and Biodentine at different setting times $(24,48,72,96 \mathrm{~h})$ " was partially accepted.

Atabek et al. ${ }^{19}$ compared the bond strength of ProRoot MTA to adhesive systems after different hardening times (2h $45 \mathrm{~min}, 24 \mathrm{~h}, 48 \mathrm{~h}, 72 \mathrm{~h}$ and 96h) using different adhesives and showed the highest bond strength with a 2-step total etch system (One-Step Plus) in 96 hours in an in vitro study. It was suggested that the acetone content of the adhesive increases the bond strength to MTA as a result of increasing monomer diffusion due to its high vapor pressure. ${ }^{19,34}$ It was also suggested that early bonding failure occurs during initial hardening, due to the possible high water content of MTA. When the bond strength values at all hardening times were examined, they stated that the performing of an adhesive restoration on MTA should be postponed for at least 96 hours in order for MTA to achieve sufficient physical properties. ${ }^{19}$

In our study, although the highest SBS values were obtained for ProRoot MTA at 72 and 96 hours, the bond strength values were found to be higher compared to this study. The reason for this difference may be different monomer systems in the adhesive used. The Clearfil Liner Bond $\mathrm{F}$ used in our study contains 10-MDP monomer in both the primer and the adhesive. It has been reported that self-etch adhesive systems containing 10MDP monomer increase the bond strength by chemically binding the 10-MDP monomer it contains with $\mathrm{Ca}$ ions in MTA and Biodentine. ${ }^{21,35,36}$

In another study, the SBS values of ProRoot MTA were found to be higher than Angelus MTA with a one-step adhesive system (Adhese One F) compared to total etch and self-etch systems. ${ }^{37}$ The reason reported for this is that ProRoot MTA has fewer large particles and more homogeneous distribution compared to Angelus MTA. They assumed that these structures are calcium silicate and calcium silicate hydrate, and it was suggested that they form the basis of the binding phases in a hydrated Portland cement-based material. ${ }^{38,39}$ It was reported that acid application on the MTA surface has an erosive effect on the MTA surface and causes cracks on the surface, but self-etch 
primer application does not create cracks on MTA surface. ${ }^{37}$ In addition, it was suggested that the content with 5\% filler ratio of Adhese One F, which is a one-step adhesive system, causes a lower shrinkage stress and increases the bond strength. ${ }^{40}$ Furthermore, it was reported that potassium fluoride increases the surface strength of Portland cement in several engineering reports. ${ }^{41,42}$ An increase in surface strength can also result in reduced cohesive failure and increased bond strength. The fluoride content of Clearfil Liner Bond F may also contribute to its high bond strength in our study.

In a study by Odabaş et al., no significant difference was observed between the SBS of different adhesive systems after Biodentine's hardening time of 12 minutes and 24 hours. In addition, the highest SBS was obtained with Clearfil SE Bond (19.5 MPa) at a hardening time of 24 hours, and Clearfil SE Bond was the only adhesive system that provided sufficient SBS among all adhesives used. There was no significant difference in SBS between Clearfil SE Bond and Clearfil S3 Bond groups at different hardening times. Furthermore, the bond strength value of Clearfil SE Bond (16.9 MPa) after the hardening time of 12 minutes was found to be higher than the other 12-minute groups, although there was no statistically significant difference. ${ }^{43}$ In this study too, it was noted that 10-MDP monomer which formed chemical adhesion with the $\mathrm{Ca}$ ions in the structure of Biodentine increased the bond strength of Clearfil SE Bond. ${ }^{21}$

Moreover, Keleş and Şimsek examined the SBS of different adhesive systems to Biodentin at the end of the 12-minute hardening time. The SBS of Clearfil SE Bond (14.1 MPa), a two-step selfetch adhesive used in the study, was found to be higher than other adhesive systems (a single-step self-etch; Clearfil Universal Bond, a two-step total etch; Prime\&Bond NT). ${ }^{30}$ Çolak et al. ${ }^{36}$ examined the SBS of different adhesive systems to Biodentine hardened for 9 minutes and 48 hours and reported that the hardening time did not affect the SBS values, but the adhesive containing 10MDP (Clearfil S3 Bond) showed higher bond strength.
Aksoy and Ünal obtained the lowest SBS value in the group set for 12 minutes by applying different universal adhesive systems in both selfetch and total-etch modes at the end of five different setting times $(12 \mathrm{~min}, 24 \mathrm{~h}, 48 \mathrm{~h}, 72 \mathrm{~h}$, $96 \mathrm{~h})$ of Biodentine. They also noted that there was no significant difference between self-etch and total-etch modes of universal adhesives in all the groups. They reported that the setting time of 24 hours is enough to obtain sufficient SBS and that the universal adhesives provide higher SBS regardless of the application mode of the adhesive systems used in the study. ${ }^{44}$ In our study, Biodentine showed sufficient bond strength in 24 hours, and there was no significant difference between the groups in which the hardening time was increased.

On the other hand, Nekoofar et al. examined the bond strength of several different resin restorative materials with Biodentine, dividing Biodentine samples into groups according to three different hardening times (12 minutes, 1 week and 1 month). Biodentine samples hardening for 1 week were found to have significantly higher micro-SBS than those with 12-minute hardening time. In the study, it was noted that the bond strength of Biodentine, which is porous and lowresistant in the early stage, may decrease with the application of adhesive agent and polymerization shrinkage of the composite resin. It was reported that CSB materials that harden with hydration are not only weak in crystallized structures at the early stage, but also porous, but these materials complete their maturation after a certain period of time. However, in this study where the etch-rinse adhesive system was used, there was no significant difference in bond strength values between Biodentine samples hardened for one week and one month. The universal adhesive material (All Bond Universal) in self-etch mode applied to the Biodentine samples after 12 minutes of hardening exhibited significantly higher average micro-SBS compared to the other groups (Clearfil SE Bond, Adper Single Bond 2). In addition, it was reported that higher SBS values can be achieved with all adhesives if a longer waiting time can be planned after mixing 
Biodentine. ${ }^{45}$ In our study too, Biodentine showed sufficient SBS in four different setting times (24h, $48 \mathrm{~h}, 72 \mathrm{~h}, 96 \mathrm{~h})$. Differences in study findings may be due to differences in material method.

Hashem et al. investigated the bond strength of Biodentine in the early $(0 \mathrm{~min} ., 5 \mathrm{~min} ., 20 \mathrm{~min}$. and 24 hours) and late period ( 2 weeks, 1 month, 3 months and 6 months) with total etch and selfetch systems. In the study, the highest $\mu$ SBS in the early period was obtained in the 24-hour group. ${ }^{46}$ However, in clinical applications, it has been suggested to extend the hardening time of Biodentine, since placing Biodentine in cavities with high $\mathrm{C}$ factor will increase polymerization stress. A 2-week waiting period is recommended for Biodentine to fully mature and reach maximum physicochemical properties. ${ }^{47}$ As a result of the study, while there was no significant difference between all hardening times in the late period, it was noted that $\mu$ SBS values were significantly higher than the early period. Moreover, there was no significant difference between the 24-hour hardening time and the late period. In this study, ScotchBond Universal adhesive containing MDP monomer was used in self-etch mode. ${ }^{46}$ Similarly, in our study, there was no significant difference between the SBS value of Biodentine in the 24-hour hardening time and the groups with the other hardening times (48h, 72h, 96h). The possible reason for obtaining similar results to this study may be the use of adhesive containing MDP monomer in our study too.

In the study performed by Tulumbac1 et $\mathrm{al}^{48}$, the SBS of MTA was found to be higher than Biodentine using Prime\&Bond NT after 72 hours of hardening time for both capping materials. In our study, however, there was no significant difference between SBS after 72 hours of hardening in both groups, and the highest bonding values were obtained. The use of different adhesive systems in this study and the differences in sample preparation for the SBS test may also have caused differences in the study results.

In the study where Cantekin and Avci hardened Biodentin and ProRoot MTA in two different periods of 15 minutes and 96 hours and then All-Bond 2 total etch adhesive system was applied, the Biodentine group showed the highest SBS value (17.7 MPa). They noted that the reasons for the high SBS value were the low level of free radical monomer and polymerization shrinkage of the methacrylate-based composite resin (Aelite All Purpose Body, Bisco Inc) they used. In addition, it was suggested that the restorative treatment be delayed for 72 hours to 96 hours in order for MTA to reach the most suitable physical properties in the capping process with MTA. ${ }^{22}$ In our study, MTA showed sufficient SBS at all hardening times. Moreover, in our study, the highest SBS value was obtained in the MTA72 and then in the MTA96 groups, which is consistent with the recommendation in this study.

In a study by Abdel-Rhman et al. ${ }^{31}$, it was proposed that MTA provided the desired impermeability after at least 72 hours and recommended waiting for 72 hours before the restoration. It was also reported that although the initial setting reaction of Biodentin takes 12 minutes after mixing powder and liquid, Biodentin gains its full physical properties after 2 weeks. ${ }^{49}$ In our study, however, there was no statistically significant difference between the SBS values of Biodentin at different hardening times, and it was observed that the SBS was similar in all setting times (24h, 48h, 72h, 96h). Again in our study, although there was no statistically significant difference in the MTA group, the highest bond strength was obtained after 72 hours.

Although there are different results regarding the bond strength of MTA and Biodentine to restorative materials, it is important for the durability of bond strength that these materials have reached sufficient maturation before restoration. Additionally, the bonding of capping materials to dentin as well as restorative materials is very important in terms of both sealing and durability of the restoration in the long term. As a matter of fact, there are many studies on the bond strength of these materials to dentin. ${ }^{51-53}$

In the study by Kaup et al., in which ProRoot MTA and Biodentine's bond strength to dentin was examined, the SBS of the groups with 2 days, 
7 days and 14 days was evaluated and the SBS of MTA was found to be significantly lower than Biodentine in the groups hardened for 2 days. In the study, it was noted that the SBS values of MTA and Biodentine, which were hardened for 7 days and 14 days, increased significantly compared to the 2-day values. Biodentine was found to be superior to ProRoot MTA in terms of the SBS values. ${ }^{50}$ In the study by Jantarat et al. ${ }^{51}$, the SBS of MTA and Biodentine to dentin was evaluated at the end of 60 minutes and 24 hours, and the SBS values of MTA and Biodentine hardened for 24 hours were found to be significantly higher. Atmeh et al. ${ }^{11}$ reported that when Biodentine is applied on dentin, it forms alkaline bonding with its high $\mathrm{pH}$ value and forms Biodentine lattices in the dentinal tubules, which shows dentin-like adhesion-like structures.

Additionally, in clinical conditions, there is a high risk of contamination of capping materials with blood or saliva during the applying of adhesive resins. It is known that contamination reduces the bond strength of restorative materials to dentin. ${ }^{32,33,54}$ Contamination of capping materials with blood are mostly studies evaluating the bond strength to dentin. ${ }^{52,55-57}$

To the best of our knowledge, there is no study in the literature on the effect of blood contamination of pulp capping materials on the SBS to adhesive resins before permanent restoration. Therefore, in this study, the effect of blood contamination on SBS after different hardening times was investigated.

According to the findings of this study, blood contamination decreased the SBS value at different hardening times in all MTA groups $(p<0.01$ for Cont. MTA24, 48, 96; $p<0.05$ for Cont MTA72). In the Biodentine groups too, blood contamination significantly decreased the bond strength at all hardening times $(\mathrm{p}<0.01$ for Cont Biodentine 24, 48, 96; $\mathrm{p}<0.05$ for Cont Biodentine72). Therefore, the second hypothesis of our study, "Contamination of ProRoot MTA and Biodentine with blood after different hardening times $(24,48,72,96$ hours) does not affect the shear bond strength of a self-etch adhesive", was not accepted. We could not discuss the findings of this phase of our study, as we could not find a study examining the SBS of capping materials to adhesive resins after contamination.

In the literature, there are studies on the bond strength of contamination to dentin tissue at different stages of restorations. ${ }^{33,54}$ Although the bond strength to dentin was not investigated in our study, it has been reported in the studies that blood contamination reduces the bond strength to dentin and that it especially adversely affects the bond strength of dentin before and after the application of adhesive systems. ${ }^{56,57}$ Procedures such as washing and drying with cotton to remove blood contamination during restorative treatments could also create effects that reduce bond strength. Therefore, since exposure to blood is inevitable when applying CSB capping materials to the exposure surface in clinical conditions, prolonging the hardening time to at least 72 to 96 hours could increase the bond strength of pulp capping materials to both dentin and composite restoration.

In this study, the SBS of both MTA and Biodentine to adhesive resins after different hardening times and after they were contaminated with blood was investigated, and a decrease in SBS bond strength was observed in all hardening groups compared to the uncontaminated groups. In addition, the SBS values of Cont MTA48, Cont MTA72, Cont MTA96 groups in contamination groups are between and very close to clinically acceptable bond strength values. The longest hardening time within the limits of this study was 96 hours.

Whether longer hardening times would affect the bond strength could be investigated in future studies. Moreover, studies in which saliva or both contamination materials are used in addition to blood contamination may be more clinically meaningful. In this study, the SBS of ProRoot MTA and Biodentine with only one self-etch adhesive was examined, and differences that may occur with different adhesive systems were not observed. Furthermore, in this study, the early SBS values of MTA and Biodentine were examined. In vitro and clinical studies, in which 
different adhesive resins of these CSB capping materials, which are widely used in the clinic, are used and long-term study results and early-term bond strength values are compared, will also contribute to the literature.

\section{CONCLUSIONS}

In this in vitro study, the effects of different hardening times $(24 \mathrm{~h}, 48 \mathrm{~h}, 72 \mathrm{~h}, 96 \mathrm{~h})$ and blood contamination of CSB pulp capping materials (Biodentine, MTA) on the SBS to a self-adhesive (Clearfil Liner Bond F) were investigated. Although hardening MTA and Biodentine at different times did not have a negative effect on the SBS, contamination with blood negatively affected the SBS of both capping materials. However, SBS values increased with the prolongation of the hardening time of MTA (72 and 96 hours) in the contaminated groups.

Beyond this study, which examines the hardening times of different capping materials and the effect of contamination on the bond strength, there is a need for studies examining the effect of longer hardening times and different contamination agents on the bond strength of both restorative materials and dentin tissue with different adhesive systems.

\section{Kan Kontaminasyonun Kalsiyum Silikat Esaslı Kuafaj Materyallerinin Makaslama Bağlanma Dayanımına Etkisi}

\section{$\ddot{O} Z$}

Amaç: Bu çalışmanın amacı piyasada yaygın olarak kullanilan kuafaj materyalleri olan MTA ve Biodentin'in farkl sertleşme süreleri (24, 48, 72 ve 96 saat) sonrasinda kanla kontaminasyonunun ve sertleşme sürelerinin bir self etch adeziv rezinle makaslama bağlanma dayanımına (MBD) etkisinin incelenmesidir. Gereç ve Yöntemler: Bu çalışma için 192 adet akrilik bloğa $5 \mathrm{~mm}$ çapında, $2 \mathrm{~mm}$ yüksekliğinde yuvalar hazırlandı. Blokların yarısı üretici talimatlarına göre hazırlanan ProRoot MTA ve diğer yarısı ise Biodentin ile dolduruldu. Tüm örnekler 4 farklı sertleşme süresine göre gruplara ayrldı ve sertleştirildi. Sertleşme süreci tamamlandıktan sonra, herbir sertleşme süresinin grubu kontaminasyonlu ve kontaminasyonsuz olarak 2 alt gruba (n:12) ayrldd. Kontamine olmayan gruplarda, örnek yüzeylerine bir self etch adeziv rezin (Clearfil Liner Bond) ve bir rezin esasll kompozit (Filtek P60) uygulandl ve polimerize edildi. Kontamine olan gruplarda ise örnek yüzeyleri 20 saniye kanla kontamine edildi. Örnekler yıkanıp kurulandiktan sonra adeziv rezin ve kompozit uygulamast yapıldı. MBD testlerinden sonra elde edilen veriler 2-yönlü ANOVA testine tabi tutuldu. Bulgular: Kontamine olmamış gruplarda her bir kuafaj materyalinin zamana bağll olarak farkl sertleşme süreleri arasında bağlanma dayanım değerleri arasında anlamlı bir fark görülmedi $(p>0,05) .72$ ve 96 saatlik kontamine olmayan gruplarda ProRoot MTA, Biodentin'e göre istatistiksel olarak daha yüksek makaslama bağlanma dayanımı gösterdi $(p<0,05)$. Kan kontaminasyonu, ProRoot MTA ve Biodentine'in $M B D$ değerlerinde önemli oranda azalmaya neden oldu ( $p<0,05)$. Sonuçlar: Bu çalışmada kan kontaminasyonunun kuafaj materyallerinin makaslama bağlanma dayanımını azalttı̆̆ tespit edilmiştir. Bu nedenle restoratif tedavilerden önce, kuafaj materyallerinin sertleşme sürelerinin uzatılmass ve kanla kontaminasyonu mümkün olduğu kadar önleyici klinik tedbirlerin alınması önerilir. Anahtar Kelimeler: Pulpa Kaplamasl; MTA; Biodentin; Kan Kontaminasyonu; Makaslama Bağlanma Dayanımı.

\section{REFERENCES}

1. Komabayashi T, Zhu Q, Eberhart R, Imai Y. Current status of direct pulp-capping materials for permanent teeth. Dental Materials Journal 2016;35:1-12.

2. Hilton TJ. Keys to clinical success with pulp capping: A Review of the Literature. Oper Dent 2009;34:615-625.

3. Ward J. Vital pulp therapy in cariously exposed permanent teeth and its limitations. Aust Endod J 2002;28:29-37.

4. Van T, Craig R, Curro F, Green W, Ship J. Treatment of deep carious lesions by complete excavation or partial removal: a critical review. J Am Dent Assoc 2008; 139:705-712.

5. Witherspoon DE, Small JC, Harris GZ. Mineral trioxide aggregate pulpotomies: a case series outcomes assessment. J Am Dent Assoc 2006;137:610-618.

6. Cox CF, Bergenholtz G, Fitzgerald M, Heys D,Heys R, Avery J, Baker J. Capping of the dental pulp mechanically exposed to the oral microflora - a 5 week 
observation of wound healing in the monkey. J Oral Pathology\&Medicine 1982;11:327-339.

7. Jefferies S. Bioactive and biomimetic restorative materials: A comprehensive review. J Esthet Restor Dent 2014;26:27-39.

8. Torabinejad M, Chivian N. Torabinejad M, Chivian N. Clinical applications of mineral trioxide aggregate. J Endod 1999;25:197-205.

9. Nowicka, A, Lipski, M, Parafiniuk, M, SporniakTutak, K, Lichota D, Kosierkiewicz, A., Kaczmarek W, Buczkowska-Radlińska J. Response of human dental pulp capped with biodentine and mineral trioxide aggregate. J Endod 2013;39:743-747.

10. Jefferies SR. Bioactive and biomimetic restorative materials:A comprehensive review. Journal of Esthetic and Restorative Dentistry 2014;26:14-26.

11. Atmeh A, Chang E, R, Richard G, Festy, F, Watson

T. Dentin cement interfacial interaction: calcium silicates and polyalkenoates. J Dent Res 2012;91:454459.

12. Donnermeyer D, Bürklein $S$, Dammaschke $T$, Schäfer E. Endodontic sealers based on calcium silicates: a systematic review. Odontology 2019;107:421-436.

13. Septodont. Brochure biodentine in one session. Available from: at http://www.septodont.in > sites > files > Brochure.

14. Malkondu Ö, Kazandağ M, Kazazoğlu E. A review on biodentine, a contemporary dentine replacement and repair material. Biomed Res Int 2014;16. Article ID 160951.

15. Youssef A, Emara R, Taher M, Al-Allaf F,Almalki M, Almasri M, Siddiqui S. Effects of Mineral trioxide aggregate, calcium hydroxide, Biodentine and Emdogain on osteogenesis, odontogenesis, angiogenesis and cell viability of dental pulp stem cells. BMC Oral Health 2019;19:133. PMID: 31266498.

16. Camps J, Pashley D. Reliability of the dye penetration studies. J Endod. 2003;29:592-594.

17. Caron G., Azerad J, Faure MO, Machtou P, Boucher Y. Use of a new retrograde filling material (Biodentine) for endodontic surgery: Two case reports.
Int J Oral Sci. 2014;6:250-253.

18. Zanini M, Sautier J, Berdal A, Simon S. Biodentine induces immortalized murine pulp cell differentiation into odontoblast-like cells and stimulates biomineralization. J Endod 2012;38:1220-1226.

19. Atabek D, Sillelioglu H, Ölmez A. Bond strength of adhesive systems to mineral trioxide aggregate with different time intervals. J Endod. 2012;38:1288-1292.

20. Biçer H, Bayrak Ş. Vital pulpa tedavisinde kullanılan kalsiyum silikat içerikli biyomateryallerin restoratif materyallere bağlanma dayanımının değerlendirilmesi. Selcuk Dent J. 2019;279:271-279.

21. Yoshida $Y$, Nagakane K, Fukuda R, Nakayama $Y$, Okazaki M, Shintani H, Inoue S, Tagawa Y, Suzuki K, De Munck J, Van Meerbeek B. Comparative study on adhesive performance of functional monomers. J Dent Res. 2004;83:454-458.

22. Cantekin K, Avcı S. Evaluation of shear bond strength of two resin-based composites and glass ionomer cement to pure tricalcium silicate-based cement (Biodentine ${ }^{\circledR}$ ). J Appl Oral Sci. 2014;22:302306.

23. Salem Milani A, Rahimi S, Froughreyhani M, Vahid Pakdel M. Effect of blood contamination on marginal adaptation and surface microstructure of mineral trioxide aggregate: A SEM study. Journal of Dental Research, Dental Clinics, Dental Prospects 2013;7:157-163.

24. Rajasekharan S, Martens LC, Cauwels RGEC, Anthonappa RP, Verbeeck RMH. Correction to :Biodentine ${ }^{\mathrm{TM}}$ material characteristics and clinical applications: a 3 year literature review and update. Eur Arch Paediatr Dent. 2018;19:1-22.

25. Parirokh M, Torabinejad M. Mineral trioxide aggregate: a comprehensive literature review-part I: Chemical, Physical, and Antibacterial Properties. J Endod. 2010;36:16-27.

26. Kunert M, Szymanska ML. Bio-inductive materials in direct and indirect pulp capping-A Review Article. Materials. 2020;13:1204.

27. Laurent P, Camps J, About I. BiodentineTM induces TGF- $\beta 1$ release from human pulp cells and early dental pulp mineralization. Int. Endod. J 2012;45:439-448. 
28. Kim J, Song YS, Min, KS., Kim, SH, Koh JT, Lee BN, Chang H, Hwang IN, Oh WM, Hwang YC. Evaluation of reparative dentin formation of ProRoot MTA, Biodentine and BioAggregate using micro-CT and immunohistochemistry. Restor. Dent. Endod. 2016;41:29.

29. Aguilar P LP. Vital pulp therapy in vital permanent teeth with cariously exposed pulp: A systematic review. J Endod. 2011;37:581-587.

30. Keles S, Derelioglu SS. Shear bond strength of composite and compomer to Biodentıne ${ }^{\circledR}$ applied with various bonding agents: An in-vitro study. Atatürk Üniv Diş Hek Fak Dergisi 2019;29:49-54.

31. Abdel-Rhman, AO, El-Din MN, Mohamed MH. Evaluation of shear bond strength of self-adhering flowable composite to mineral trioxide aggregate and biodentine. Al-Azhar Dent J. 2019;6:153-159.

32. Chang SW, Cho BH, Lim RY, Kyung SH, Park DS, Oh TS, Yoo H. Effects of blood contamination on microtensile bond strength to dentin of three self-etch adhesives. Oper Dent. 2010;35:330-336.

33. Oonsombat C, Bishara SE, Ajlouni R. The effect of blood contamination on the shear bond strength of orthodontic brackets with the use of a new self-etch primer. Am J Orthod Dentofac Orthop. 123;5:547-550.

34. Silva E Souza MH, Carneiro KG, Lobato MF, Silva e Souza Pde A, de Góes MF. Adhesive systems: Important aspects related to their composition and clinical use. J Appl Oral Sci 2010;18:207-214.

35. Hashem DF, Foxton R, Manoharan A, Watson TF, Banerjee A. The physical characteristics of resin composite-calcium silicate interface as part of a layered/laminate adhesive restoration. Dent Mater 2014;30:343-349.

36. Çolak H, Tokay U, Uzgur R, Uzgur Z EE, Hamidi MM. The effect of different adhesives and setting times on bond strength between Biodentine and composite. J Appl Biomater Funct Mater. 2016;14:217-222.

37. Shin JH, Jang JH, Park SH, Kim E. Effect of mineral trioxide aggregate surface treatments on morphology and bond strength to composite resin. $\mathbf{J}$ Endod 2014;40:1210-1216.

38. Reyes-Carmona JF, Felippe MS, Felippe WT. Biomineralization ability and interaction of mineral trioxide aggregate and white portland cement with dentin in a phosphate-containing fluid. $\mathrm{J}$ Endod 2009;35:731-736.

39. Smith JB, Loushine RJ, Weller RN, Rueggeberg FA, Whitford GM, Pashley DH, David HT, Franklin R. Metrologic evaluation of the surface of white MTA after the use of two endodontic irrigants. J Endod 2007;33:463-467.

40. Scientific Documentation of AdheSE One F. Available at: http://www.ivoclarvivadent. co.kr.

41. Kim JO, Nam NJ. Changes in hydration and water tightness of cement containing two component fluosilicate salt based chemical admixture. J Kor Ceram Soc 2004;41:749-755.

42. Yan IS, Yun HD, Kim DS. Experimental study on engineering properties of concrete using fluosilicate based composite. J Korea Concr Inst. 2005;17:769774.

43. Odabaş ME, Bani M, Tirali RE. Shear bond strengths of different adhesive systems to biodentine. Sci World J. 2013;10:626103.

44. Aksoy S, Ünal M. Shear bond strength of universal adhesive systems to a bioactive dentin substitute (Biodentine ${ }^{\circledR}$ ) at different time intervals. Stomatol Dis Sci 2017;1:116-122.

45. Nekoofar MH, Fariba M, Mirzaei M, Yassini E, Pouyanfar H, Dummerb PMD. The micro-shear bond strength of various resinous restorative materials to aged Biodentine. Iran Endod J 2018;13:356-361.

46. Hashem DF, Foxton R, Manoharan A, Watson TF, Banerjee A. The physical characteristics of resin composite-calcium silicate interface as part of a layered/laminate adhesive restoration. Dent Mater. 2014;30:343-349.

47. Bachoo IK, Seymour D, Brunton P. A biocompatible and bioactive replacement for dentine: Is this a reality? The properties and uses of a novel calcium-based cement. British Dent J. 2013; E5:1-7.

48. Tulumbaci F, Almaz ME, Arikan V Mutluay MS. Shear bond strength of different restorative materials to mineral trioxide aggregate and Biodentine. J Conserv Dent. 2017;20:292-296.

49. Buldur B, Öznurhan F, Kayabaşı M A, Şahin F. 
Shear bond strength of two calcium silicatebased cements to compomer. Cumhur Dent J 2018;21:18-23.

50. Kaup M, Dammann CH, Schäfer E, Dammaschke T. Shear bond strength of Biodentine, ProRoot MTA, glass ionomer cement and composite resin on human dentine ex vivo. Head Face Med 2015;11:1-8.

51. Jantarat J, Ritsayam S, Banomyong D, Chaimanakarn C. Early and 24-hour shear bond strength to dentine of three calcium silicate based pulp capping materials. M Dent J 2018;38:177-183.

52. Pradeep PS, Randhya R, Shanavas $P$, Mushina K, Hima S. An in vitro comparative evaluation of shear bond strength of biodentine and MTA. Int J Appl Dent Sci 2018;4:1-3.

53. Aşıcıoğlu D, Sonat B. Comparison of push-out bond strength of two different sized furcation perforations with three different materials. AÜ Diş Hek Fak Dergisi 2018;45:133-143.
54. Cunha TMA, Behrens BA, Nascimento D, Retamoso LB, Lon LFS, Tanaka O, Filho OG. Blood contamination effect on shear bond strength of an orthodontic hydrophilic resin. J Appl Oral Sci 20;1:8993.

55. Adl A, Sobhnamayan F, Sadatshojaee N, Azadeh $\mathrm{N}$. Effect of blood contamination on the push-out bond strength of two endodontic biomaterials. J Restor Dent 2016;4:59.

56. VanderWeele RA, Schwartz SA, Beeson TJ. Effect of blood contamination on retention characteristics of mta when mixed with different liquids. J Endod 2006;32:421-424.

57. Ashofteh Yazdi K, Bolhari B, Sabetmoghaddam T, Meraji N, Kharazifard MJ. Effect of blood exposure on push-out bond strength of four calcium silicate based cements. Iran Endod J 2017;12:196-200. 